\title{
Rheology, clinical efficacy and sensorial of a silicone-based formulation containing pearl extract
}

\author{
Reologia, eficácia clínica e sensorial de uma formulação baseada em silicone contendo \\ extracto de pérola
}

\author{
Ana Flora V. S. Marcon, Tais A. L. Wagemaker, Patrícia M. B. G. Maia Campos \\ University of São Paulo, Faculty of Pharmaceutical Sciences of Ribeirão Preto, Brazil \\ Email: pmcampos@usp.br
}

\begin{abstract}
In traditional Chinese medicine, pearl extract is believed to nourish skin and prevent the aging process. Thus, the aim of this study was to evaluate rheological characteristics, immediate effects on skin, and sensory properties of a silicone-based cosmetic formulation containing pearl extract. Formulations containing pearl extract or not were submitted to physical stability assays by determinations of its rheological behavior during 28 days storage. Once confirmed the formulation's stability, they were applied on the volar forearm of 15 healthy female to evaluate skin properties by non-invasive techniques. After a single application, formulations increased the stratum corneum water content. Once applied on the volar forearm for sensory analysis, the volunteer's majority noted that both formulations improved all the sensory skin attributes, but only the pearl extract formulation has shown the higher scores for all attributes. Results suggested that the silicone-based formulation supplemented with the pearl extract could combine unique sensory properties and effectiveness to better meet consumer's demand.
\end{abstract}

Keywords: Silicone, Pearl Extract, Rheological Behavior, Biophysical Techniques, Sensory Analysis

\section{Resumo}

$\mathrm{Na}$ medicina tradicional chinesa, acredita-se que o extracto de pérola pode nutrir a pele e prevenir o processo de envelhecimento. Assim, o objectivo deste estudo foi avaliar as características reológicas, os efeitos imediatos sobre a pele e as propriedades sensoriais de uma formulação cosmética à base de silicone contendo extracto de pérola. As formulações contendo extrato de pérola ou não foram foram submetidas a ensaios de estabilidade física por determinação do comportamento reológico durante 28 dias de armazenamento. Uma vez que as formulações se mostraram estáveis, elas foram aplicadas na região interna do antebraço de 15 indivíduos saudáveis do sexo feminino para avaliar as condições da pele usando técnicas não-invasivas. Após uma única aplicação, as formulações aumentaram o conteúdo de água do estrato córneo. Quando as formulações foram aplicadas no antebraço para a análise sensorial, a maioria dos voluntários notaram que ambas as formulações melhoraram todos os atributos sensoriais da pele, mas que apenas a formulação com extrato de pérola mostrou as maiores notas para todos eles. Os resultados sugerem que a formulação à base de silicone adicionada de extracto de pérolas pode combinar propriedades sensoriais únicas e eficácia para melhor atender a demanda dos consumidores.

Palavras-chave: Silicone, Extracto de pérola, Comportamento reológico, Técnicas de biofísica, Análise Sensorial. 


\section{Introduction}

Pearl extract is obtained from a combination of aragonite $\left(\mathrm{CaCO}_{3}\right)$ and traces of a conchiolin protein called nacre. Due to its rich composition, mainly essential amino acids and minerals, traditional Chinese medicine indicates that pearl powder can nourish the skin and slow down aging processes by improving the metabolism, supporting skin hydration and protecting against environmental damage effects ${ }^{(1)}$. However, despite its ancient tradition for Chinese medicinal purposes, there is a lack of studies regarding the properties of pearl extract applied in cosmetic formulations.

Silicones have been incorporated in personal care products since the 1950s and, since then, they are becoming increasingly important in the pharmaceutical and cosmetic industry because of their versatility, low cost, and technological advantages ${ }^{(2)}$.

Silicones are preferred ingredients in "oil-free formulations" likely due to their lubricating properties and for the characteristic soft velvety feel they impart to the skin. During application, silicones can provide a specific sensation upon first touch and removal from the container, then aid the product in spreading easily on the skin and helping to promote its absorption ${ }^{(3)}$.

Used together, silicone and pearl extract combine unique aesthetics and sensory properties which can influence stability, efficacy and sensorial of cosmetic formulations. Thus, the aim of this study was to evaluate the rheological behavior, short-term clinical efficacy and sensorial properties of a silicone-based cosmetic formulation containing pearl extract.

\section{Material and methods}

\section{Formulations}

The formulation under study was composed of deionized water, cyclopentasiloxane, dimethicone, crosspolymer, dimethicone, laureth-23 and laureth-4 (Elastomer blend HIP emulsion Dow Corning ${ }^{\circledR} 7-3101$, Dow Corning, USA ), glycerin PA, ammonium acryloyldimethyltaurate/VP copolymer (Aristoflex ${ }^{\circledR}$ AVC, Clariant International Ltd, Switzerland) and phenoxyethanol, methylparaben, ethylparaben, butylparaben, propylparaben, and isobutylparaben (Phenova ${ }^{\circledR}$, Croda International Plc, United Kingdom), to which was added, or not (vehicle), $5 \%$ of pearl extract (Pearl Extract ${ }^{\mathbb{B}}$, Crodarom, France).

\section{Introdução}

O extracto da pérola é obtido a partir de uma combinação de aragonite $\left(\mathrm{CaCO}_{3}\right)$ e resíduos de proteínas conchiolina chamada nácar. Devido à sua composição rica principalmente em aminoácidos essenciais e minerais, a medicina tradicional chinesa acredita que o pó de pérola pode nutrir a pele e retardar os processos de envelhecimento, melhorando o metabolismo, melhorando a hidratação da pele e protegendo contra os efeitos de danosos ambientais ${ }^{(1)}$. No entanto, apesar de sua tradição milenar para fins medicinais chineses, há uma carência de estudos sobre as propriedades do extracto de pérola, principalmente quando aplicado em formulações cosméticas.

Os silicones foram incorporadas em produtos de cuidados pessoais, desde a década de 1950 e, desde então, eles estão se tornando cada vez mais importantes na indústria farmacêutica e cosmética, devido à sua versatilidade, baixo custo e vantagens tecnológicas ${ }^{(2)}$.

Os silicones são preferidos ingredientes em formulações "oil-free" provavelmente devido às suas propriedades de lubrificação e para a conferir característica aveludada à pele. Durante a aplicação, os silicones podem proporcionar uma sensação táctil específica no primeiro toque e na remoção do recipiente, em seguida, o produto auxilia no espalhamento sobre a pele e ajuda a promover a sua absorção ${ }^{(3)}$.

Juntos, silicone e extracto de pérolas combinam uma estética única e propriedades sensoriais que podem influenciar a estabilidade, eficácia e sensorial de formulações cosméticas. Assim, o objetivo deste estudo foi avaliar o comportamento reológico, a eficácia clínica a curto prazo e as propriedades sensoriais de uma formulação cosmética à base de silicone contendo extracto de pérola.

\section{Material e métodos}

\section{Formulações}

A formulação deste estudo foi composta de água deionizada, cyclopentasiloxane, dimethicone, crosspolymer, dimethicone, laureth-23 e laureth-4 (Elastomer blend HIP emulsão Dow Corning ${ }^{\circledR} 7-3101$, Dow Corning, EUA ), glycerin PA, ammonium acryloyldimethyltaurate/VP copolymer (Aristoflex ${ }^{\circledR}$ AVC, Clariant International Ltd, Suiça) e, phenoxyethanol , methylparaben, ethylparaben, butylparaben, propylparaben, isobutylparaben (Phenova ${ }^{\circledR}$, Croda International Plc, Reino Unido), a qual foi adicionada ou não (veículo) com $5 \%$ de extracto de pérola (Pearl Extract ${ }^{\circledR}$, Crodarom, França). 


\section{Rheological characterization of the formulations}

The rheological characterization was performed using a Brookfield Cone and Plate type rheometer, model DV-III (Brookfield, BrasEq Ltda, Brazil) with a shear rate interval of $0.2 \mathrm{rpm}$ to $2.0 \mathrm{rpm}$. Samples of the two formulations were stored at room temperature $(25$ $\pm 2)^{\circ} \mathrm{C}, 37^{\circ \mathrm{C}}$ and $45^{\circ} \mathrm{C}$, for a total duration of 28 days. Formulations apparent viscosity and rheological behavior were determined at 7 days, 14 days, 21 days and 28 days. Rheograms and viscosity measurements were obtained at $\left(25^{\circ} \mathrm{C} \pm 2\right)^{\circ} \mathrm{C}$ with $0.5 \mathrm{~g}$ samples and a CP52 spindle. The consistency index and flow index were determined through the Ostwald flow model using a Brookfield software program, RHEOCALC version $\mathrm{V} 1.01^{(4)}$.

\section{Study protocol}

Approval for the study was obtained from the Faculty of Pharmaceutical Sciences of Ribeirão Preto - USP Ethics Committee (CEP/FCFRP 135/2008). Fifteen healthy female subjects, 18 years - 45 years old, having Fitzpatrick skin types II, III and IV, participated in this study after have given their informed consent.

The exclusion criteria were: presence of any dermatitis and/or other skin or allergic diseases, smokers and previous treatment of skin forearms with cosmetic formulations such as moisturizers, sunscreens or anti-aging cosmetics.

Prior to all measurements, subjects remained in the room for at least 20 minutes in order to allow skin adaptation to room temperature $(22 \pm 2){ }^{\circ} \mathrm{C}$ and relative humidity $(45 \%-60 \%)$.

The forearm skin area of each volunteer was marked in two regions in one forearm, $25 \mathrm{~cm}^{2}$ each. The formulations studied and the measurement regions were randomized.

\section{Effects after a single application (short term efficacy)}

After the baseline measurements, $100 \mathrm{mg}$ of each formulation (vehicle, vehicle $+5 \%$ of pearl extract) was applied on the volar forearm different sites. Two hours after the application, new measurements were carried out.

\section{Instrumentation}

Stratum corneum water content was measured using a skin capacitance meter (Corneometer ${ }^{\circledR}$ TM CM 825, Courage \& Khazaka Electronic GmbH, Cologne, Germany). The device determines the water content of the superficial epidermal layers to a depth of about $0.1 \mathrm{~mm}$ and expresses the values in arbitrary units. The average

\section{Caracterização reológica das formulações}

A caracterização reológica foi realizada usando um reómetro tipo Cone e Placa Brookfield, modelo DV-III (Brookfield, BrasEq Ltda, Brasil) com um intervalo de cisalhamento de $0,2 \mathrm{rpm}$ a 2,0 rpm. As amostras de ambas as formulações foram armazenadas à temperatura ambiente $(25 \pm 2){ }^{\circ} \mathrm{C}, 37{ }^{\circ \mathrm{C}}$ e $45{ }^{\circ} \mathrm{C}$, durante uma duração total de 28 dias. A viscosidade aparente e comportamento reológico das foram determinados aos 7 dias, 14 dias, 21 dias e 28 dias. Os reogramas e as medições de viscosidade foram obtidas a $\left(25^{\circ} \mathrm{C} \pm 2{ }^{\circ} \mathrm{C}\right) \operatorname{com} 0,5$ $\mathrm{g}$ de amostras e um vector CP52. O índice de consistência e o índice de fluxo foram determinados através do modelo de fluxo de Ostwald usando um programa de computador Brookfield, RHEOCALC versão V 1.01(4).

\section{Protocolo de estudo}

A aprovação para o estudo foi obtida a partir da Faculdade de Ciências Farmacêuticas de Ribeirão Preto USP Comitê de Ética (CEP/FCFRP 135/2008). Quinze voluntárias saudáveis entre 18 anos e 45 anos de idade, com tipo de pele Fitzpatrick II, III e IV, participaram deste estudo, depois de ter dado o seu consentimento informado.

Os critérios de exclusão foram: presença de qualquer dermatite e/ou outras doenças de pele ou alérgicas, fumantes e tratamento prévio da pele dos antebraços com formulações cosméticas, como hidratantes, protetores solares ou cosméticos anti-envelhecimento.

Antes de todas as medições, os indivíduos permaneceram na sala durante pelo menos 20 minutos, a fim de permitir a adaptação da pele até à temperatura ambiente $(22 \pm 2){ }^{\circ} \mathrm{C}$ e humidade relativa de $(45 \%-60 \%)$.

$\mathrm{O}$ antebraço de cada voluntária foi demarcado em duas regiões ambas com $25 \mathrm{~cm}^{2}$ cada. As formulações estudadas e as regiões de medição foram randomizadas.

Efeitos após uma única aplicação (Efeitos de curto prazo)

Após as medidas iniciais, $100 \mathrm{mg}$ de cada formulação (veículo, veículo $+5 \%$ de extracto de pérola) foram aplicadas na região interna do antebraço. Duas horas após a aplicação novas medições foram realizadas.

\section{Instrumentação}

O teor de água do estrato córneo foi medido utilizando um medidor de capacitância da pele (Corneometer ${ }^{\circledR}$ TM CM 825, Courage \& Khazaka Electronic GmbH, Colônia, Alemanha). O dispositivo determina o teor de água das camadas superficiais da epiderme até uma profundidade de cerca de $0,1 \mathrm{~mm}$ e expressa os valores 
values of five measurements per site were used in subsequent calculations ${ }^{(5)}$.

Transepidermal water loss (TEWL) was measured with an evaporimeter (Tewameter ${ }^{\circledR}$ TM 210, Courage \& Khazaka Electronic $\mathrm{GmbH}$, Cologne, Germany), and registered in $\mathrm{g} /$ $\left(\mathrm{m}^{2} \mathrm{~h}\right)$ for two minutes following probe equilibration on the skin for 90 seconds ${ }^{(5)}$.

Skin microrelief parameters were evaluated using Visioscan ${ }^{\circledR}$ VC98 and software SELS 2000 from Courage \& Khazaka Electronic Gmbh (Cologne, Germany). The measurement area was $6 \times 8 \mathrm{~mm}^{2}$ and the image of the skin was taken by a built-in CCD camera. The SELS (Surface Evaluation of the Living Skin) method is based on a graphic depiction of the living skin under special illumination, and the electronic processing and evaluation of this image was carried out according to four clinical parameters: a) Skin smoothness (Sesm) - calculated from the average width and depth of the wrinkles, b) Skin roughness (Ser) - the roughness parameter , calculating the gray levels above the threshold in comparison with the entire image (reflects the 'asperity' of the skin.), c) Wrinkles (Sew) - calculated from the proportion of horizontal and vertical wrinkles and $d$ ) Wrinkle depth $(\mathrm{Rt})^{(5)}$.

\section{Sensory evaluation}

The sensory panel was carried out by 15 female volunteers from 18 years to 45 years old. Sensory attributes were assessed according to well-defined procedures as described below. The procedures followed were in accordance with the ethical standards of the Faculty of Pharmaceutical Sciences of Ribeirão Preto (CEP/FCFRP 135/2008).

Volunteers were instructed to not use moisturizers, body lotions, soap or other occlusive cosmetic preparations on the tested area for 12 hours prior to study.

All subjects rested in a room maintained at $(25 \pm 1){ }^{\circ} \mathrm{C}$ and $40 \%-60 \%$ relative humidity for 15 minutes prior to evaluation.

The volunteers were asked to apply the product with one finger, performing the number of rubs needed to promote the absorption of $100 \mathrm{mg}$ of formulations (vehicle and formulation containing $5 \%$ of pearl extract) on the delimited area $\left(25 \mathrm{~cm}^{2}\right)$ of internal side of the forearm, i.e., $4 \mathrm{mg} / \mathrm{cm}^{2}$. The volunteers evaluated the following attributes during application: spreadability, moisturizing, softness, skin feel (during the application) and after feel (after five minutes application). A fourlevel score, with numbers from 1 - "bad" to 4 - "very good" was used to evaluate both formulations ${ }^{(6)}$.

The median of each formulation score for each evaluated sensory attribute were calculated and used to compare the formulations under study. em unidades arbitrárias. Os valores médios de cinco medições por local foram utilizados nos cálculos ${ }^{(5)}$.

Perda de água transepidérmica (PTEA) foi medida com um evaporímetro (Tewameter ${ }^{\circledR}$ TM 210, Courage \& Khazaka Electronic GmbH, Colônia, Alemanha), e registrado em $\mathrm{g} /\left(\mathrm{m}^{2} . h\right)$ durante $2 \mathrm{~min}$, após o equilíbrio sonda sobre a pele por $90 \mathrm{~s}^{(5)}$.

Os parâmetros do microrrelevo pele foram avaliados utilizando Visioscan ${ }^{\circledR}$ VC98 e software SELS 2000 da Courage \& Khazaka Gmbh Eletrônico (Colónia, Alemanha). A área de medição foi de $6 \times 8 \mathrm{~mm}^{2}$ e a imagem da pele foi tirada por uma câmera embutida CCD. O método SELS (Avaliação Superficial da Pele Viva) é baseada em uma representação gráfica da pele viva sob iluminação especial. O processamento eletrônico e avaliação desta imagem foram realizadas de acordo com quatro parâmetros clínicos: a) suavidade da pele (Sesm) - é calculada a partir da largura e profundidade média das rugas, b) rugosidade da pele (Ser) - é o parâmetro de rugosidade e calcula os níveis de cinza acima do limiar, em comparação com a imagem inteira (reflecte a "aspereza" da pele), c) rugas (SEW) - é calculada a partir da proporção de rugas horizontais e verticais e d) profundidade de rugas $(\mathrm{Rt})^{(5)}$.

\section{Avaliação sensorial}

O painel sensorial foi composto por 15 voluntárias do sexo feminino entre 18 anos e 45 anos de idade. Os atributos sensoriais foram avaliadoss de acordo com os bem-definidos procedimentos descritos abaixo.

Os procedimentos seguidos estavam de acordo com os padrões éticos da Faculdade de Ciências Farmacêuticas de Ribeirão Preto (CEP/FCFRP 135/2008).

As voluntárias foram instruídos a não usar hidratantes, loções para o corpo, sabão ou outros produtos cosméticos oclusivos na área testada por $12 \mathrm{~h}$ antes do estudo. Todos os indivíduos permaneceram em repouso numa sala mantida a $(25 \pm 1){ }^{\circ} \mathrm{C}$ e $40 \%$ - $60 \%$ de humidade relativa durante 15 minutos antes da avaliação.

Foi solicitado às voluntárias para aplicar o produto com um dedo, e executar do número de esfregas necessárias para promover a absorção de $100 \mathrm{mg}$ das formulações (veículo e formulação contendo $5 \%$ de extracto de pérola) na área delimitada $\left(25 \mathrm{~cm}^{2}\right)$, no lado interno do antebraço, ou seja, $4 \mathrm{mg} / \mathrm{cm}^{2}$. As voluntárias avaliaram os seguintes atributos durante a aplicação: espalhabilidade, hidratação, maciez, sensação na pele (durante a aplicação) e sensação na pele (depois de 5 minutos de aplicação). A atribuição de notas em quatro níveis, com os números de 1- "ruim" para 4 "muito bom" foi utilizada para avaliar ambas as formulações ${ }^{(6)}$.

A mediana de cada nota para cada formulação e para cada atributo sensorial foi calculada e utilizada para comparar as formulações em estudo. 


\section{Results}

\section{Rheological characterization of the formulations}

The rheological analysis (Figure 1) shows that both formulations, vehicle and containing pearl extract, exhibited low variations ( $C V \leq 3 \%$ ) in apparent viscosity when submitted to room temperature and to heat stress at $37^{\circ} \mathrm{C}$, and $45^{\circ} \mathrm{C}$ over 28 days, indicative of physical stability .

Regarding the flow index analysis, all formulations presented non Newtonian behavior as they showed flow index values below 1.0 ( 0.65 to 0.89 ). Therefore, they have proven to have pseudoplastic characteristics, which directly affect the formulation spreading on $\operatorname{skin}^{(7)}$

\section{Resultados}

\section{Caracterização reológica das formulações}

A análise reológica (Figura 1) mostra que tanto formulações, veículos e formulação $\mathrm{PE}$, exibiram pouca variação $(C V \leq 3 \%)$ nos valores de viscoisdade aparente quando submetidas à temperatura ambiente e ao stress térmico a $37{ }^{\circ} \mathrm{C}$ e $45^{\circ} \mathrm{C}$ ao longo de 28 dias, sugerindo a sua estabilidade física.

Em relação à análise do índice de fluxo, todas as formulações apresentaram comportamento não-newtoniano pois estas mostraram valores abaixo de 1,0 (0,65 a 0,89$)$. Portanto, elas demonstraram ter características pseudoplásticas, que afetam diretamente o espalhamento da formulação na pele ${ }^{(7)}$.
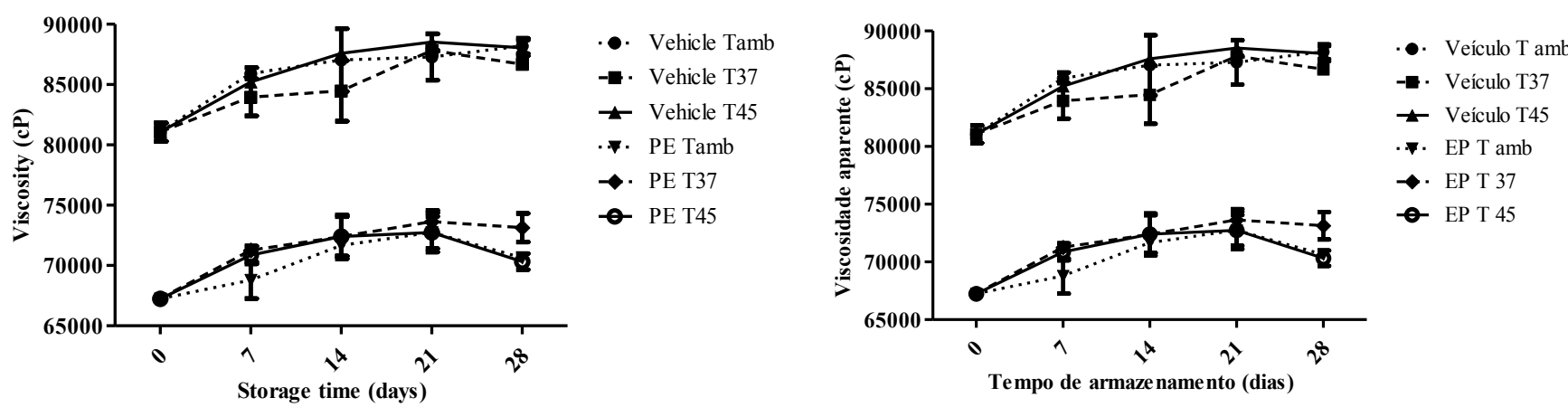

Figure 1/ Figura 1. Apparent viscosity (cP) of formulations containing or not $\mathrm{PE}$ at 25 ${ }^{\circ} \mathrm{C}, 37^{\circ} \mathrm{C}$ and $45^{\circ} \mathrm{C}(\mathrm{b})$, after 28 days storage (average of triplicates). $\mathrm{V}$ - formulation without pearl extract and $\mathrm{PE}$ - formulation with $5 \%$ of pearl extract.

Viscosidade aparente (cP) de formulações contendo ou não PE a $25^{\circ} \mathrm{C}, 37{ }^{\circ} \mathrm{C}$ e $45^{\circ} \mathrm{C}$ (b), após 28 dias de armazenamento (média de triplicatas). $\mathrm{V}$ - formulações sem extrato de pérola e PE - formulação com 5\% de extrato de pérola

\section{Effects after a single application}

In this study, stratum corneum water content measurements were used to access skin hydration, while transepidermal water loss measurements were used to access impaired barrier function. Statistical significant differences were found after two hours after application of both formulations under study: vehicle and vehicle + pearl extract (Figure 2).

Under the conditions of this study, both formulations significantly contributed to decrease the transepidermal water loss on the forearm of the volunteers (Figure 3).

The effects on skin microrelief after a single application of the formulations were accessed by Visioscan ${ }^{\circledR}$. However, there were found no statistical differences between the formulations under study and control area for all parameters under study.

\section{Efeitos após uma única aplicação}

Neste estudo, para acessar a hidratação da pele foram utilizadas medições do conteúdo aquoso do estrato córneo, enquanto que para a função de barreira prejudicada foram utilizadas medições de perda de água transepidérmica. Foram encontradas diferenças estatisticamente significativas após 2 horas, quando foi aplicado as formulações em estudo: veículo e veículo + extracto de pérola (Figura 2).

Sob as condições deste estudo, ambas as formulações contribuiram significativamente para diminuir a perda de água transepidérmica no antebraço das voluntárias (Figura 3).

Os efeitos sobre o microrrelevo pele após uma única aplicação das formulações foram acessados por Visioscan ${ }^{\circledR}$. No entanto, não foram encontradas diferenças estatísticas entre as formulações em estudo e a área de controle para todos os parâmetros em estudo. 

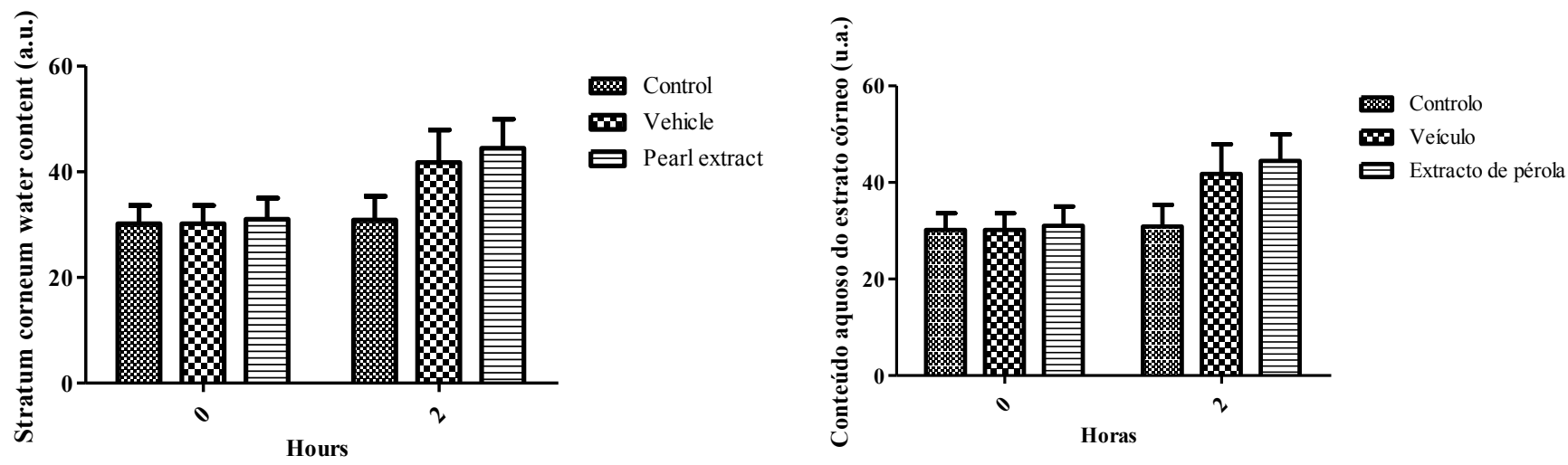

Figure 2/ Figura 2. Determination of stratum corneum water content (means + SD) for each treatment. Data was obtained by Corenometer measurements after 0 and 2 hours application $(n=15)$. Control - skin without formulation, Vehicle - formulation without pearl extract and Pearl extract - formulation containing $5 \%$ of pearl extract. * Means that are statistically different $(\mathrm{p} \leq 0,05)$.

Determinação do teor da água do estrato córneo (médias + DP para cada tratamento. Os dados foram obtidos por meio de medições Corenometer após a aplicação 0 e 2 horas $(n=15)$. Controle - pele sem formulação, veículo formulação sem extrato de pérola e extrato de pérola - formulação contendo $5 \%$ de extrato de pérola. * Meios que são estatisticamente diferentes $(\mathrm{p} \leq 0,05)$.
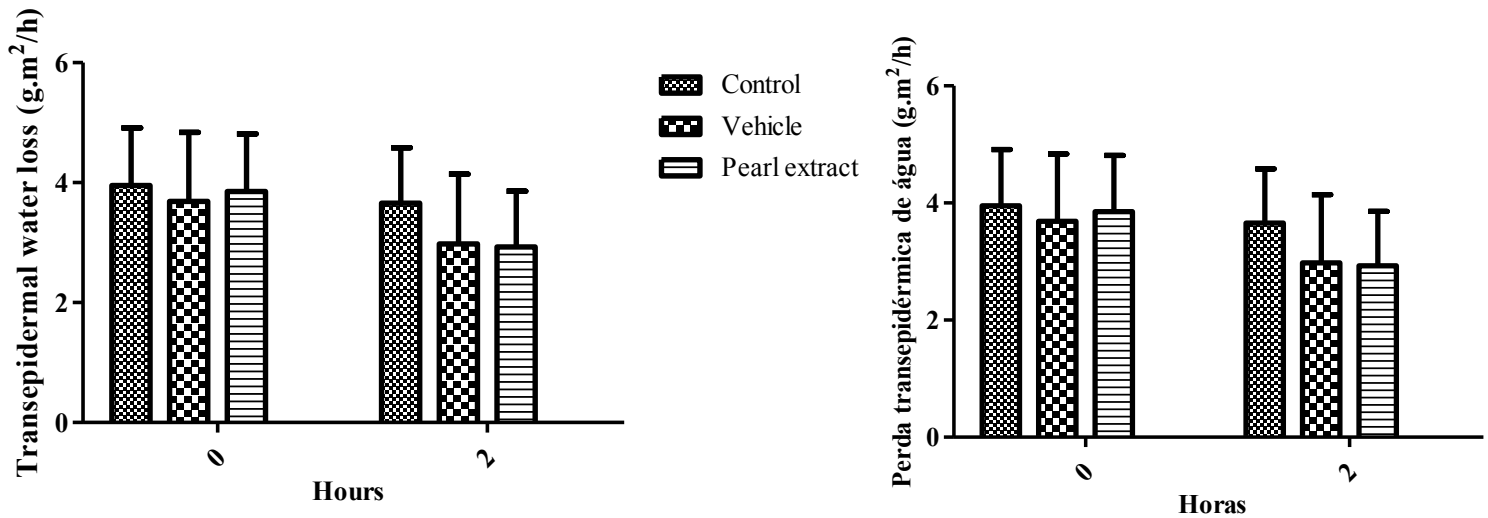

Controlo

meículo

Extracto de pérola

Figure 3/ Figura 3. Determination of transepidermal water loss (means + SD) for each treatment. Data was obtained by Tewameter measurements after 0 and 2 hours application $(n=15)$. Control - skin without formulation, Vehicle - formulation without pearl extract and Pearl extract - formulation containing 5\% of pearl extract. * Means that are statistically different $(\mathrm{p} \leq 0,05)$.

Determinação da perda de água transepidérmica (meio + SD) para cada tratamento. Os dados foram obtidos por meio de medições Tewameter após a aplicação 0 a 2 horas $(n=15)$. Controle - pele sem formulação, veículo formulação sem extrato de pérola e extrato de pérola - formulação contendo $5 \%$ de extrato de pérola. * Meios que são estatisticamente diferentes $(\mathrm{p} \leq 0,05=$

\section{Sensory evaluation}

The formulation containing pearl extract showed the highest median scores for all the sensory parameters evaluated (Figure 4), indicating that the addition of pearl extract improved the sensorial characteristics and, consequently, could result in better consumer acceptance.

\section{Avaliação sensorial}

A formulação contendo extrato de pérola apresentou as maiores medianas das notas atribuídas para todos os parâmetros sensoriais avaliados (Figura 4), o que indica que a adição de extracto de pérola melhorou as características sensoriais e, conseqüentemente, pode implicar em melhor aceitação desta pelo consumidor. 

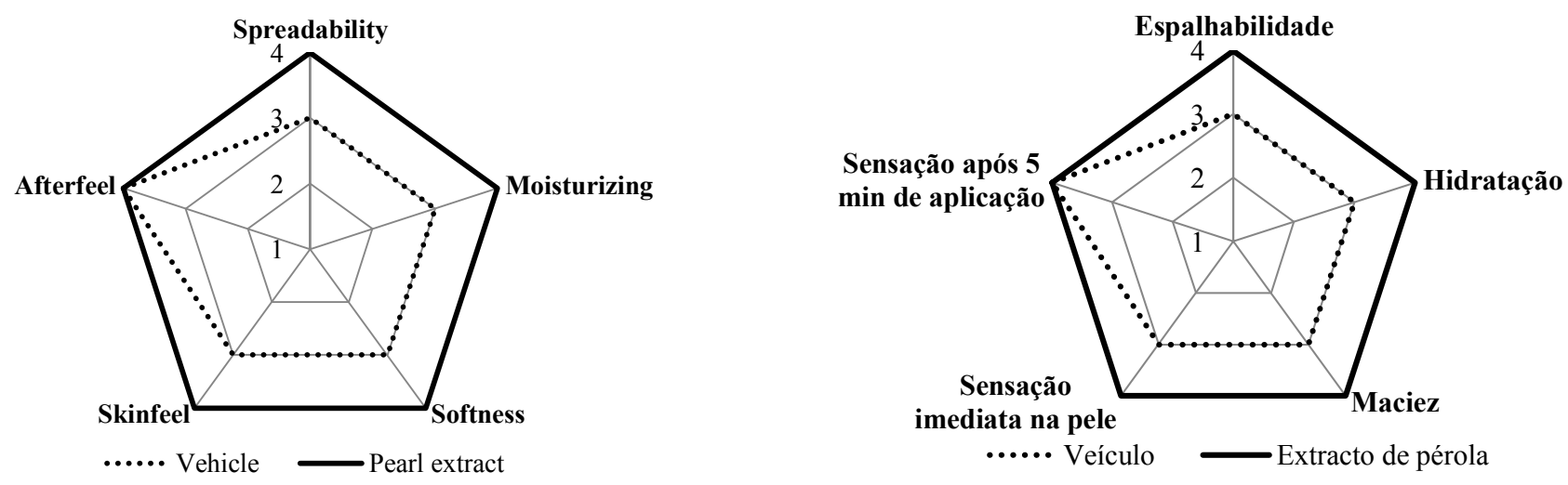

Figure 4/ Figura 4. Median of the scores attributed for each evaluated sensory property by 15 volunteers during application and five minutes after application of the formulations. Vehicle - formulation without pearl extract and Pearl extract - formulation with $5 \%$ of pearl extract.

A mediana das notas atribuídas para cada propriedade avaliada sensorialmente por 15 voluntários durante a aplicação e cinco minutos após a aplicação das formulações. Veículo - formulação sem extrato de pérola e extrato de pérola - formulação com $5 \%$ de extrato de pérola

\section{Statistical analysis}

Two-way ANOVA Test was used with Bonferroni's Test to compare formulations considering each biophysical technique parameter and the two evaluation durations (before and after two hours application). All analyses were performed using the statistical software, Graph Pad Prism 5. Differences were accepted as statistically significant at $p<0.05$.

\section{Discussion}

Viscosity is the most well-known expression of rheology. It is frequently used to monitor formulation stability over time and to define the formulation profile for best delivery as a novel product form or from specialized packaging ${ }^{(3)}$. The same authors also state that rheology has become increasingly important because an understanding of its parameters has allowed formulators to optimize the sensory and performance attributes of personal care products.

All formulations showed pseudoplastic behavior. According to Wagemaker et al. ${ }^{(4)}$, this rheological behavior allowed the formulation to show smooth flow after applying a tension, and therefore leading to great dispersion during application and formation of a uniform film on skin surface.

Both formulations showed low viscosity variations which can indicate their physical stability even though under stress temperature conditions.

\section{Análise estatística}

Análise de variância de duas vias foi utilizada juntamente com o teste de Bonferroni para comparar as formulações considerando cada parâmetro de biofísica e duas durações de avaliação (antes e após 2 horas de aplicação). Todas as análises foram realizadas utilizando o software estatístico, Graph Pad Prism 5. As diferenças foram aceitas como estatisticamente significativos quando $p<0,05$.

\section{Discussão}

A viscosidade é a expressão mais bem conhecido de reologia. Esta é freqüentemente utilizada para monitorar a estabilidade da formulação ao longo do tempo e definir o perfil de formulação para a melhor permeação ou para embalagens especializadas ${ }^{(3)}$. Os mesmos autores também afirmam que Reologia tornou-se cada vez mais importante, porque a compreensão de seus parâmetros permitiu aos formuladores otimizar os atributos sensoriais e a performance de produtos para cuidados pessoais. Todas as formulações apresentaram comportamento pseudoplástico. De acordo com Wagemaker et al. ${ }^{(4)}$, este comportamento reológico permitiu a formulação mostrar fluxo suave após a aplicação de uma tensão, e, por conseguinte, leva à grande dispersão durante a aplicação e formação de um filme uniforme sobre a superfície da pele.

Ambas as formulações apresentaram pouca variação na viscosidade, o que pode indicar a sua estabilidade física, mesmo que sob condições de estresse térmico. A formulação contendo extracto de pérola exibiu va- 
The formulation containing pearl extract exhibited lower apparent viscosity values (Figure 1) likely due to the hydrophilic characteristic of this extract.

Pleasant skin feel and after feel of silicone-based formulations are widely described in literature. After application, silicones can contribute to skin smoothness, provide luster or a matte appearance, add a perception of moisturizing, impart lubrication without tackiness, or give a soft, dry, even powdery feel ${ }^{(3)}$.

Sensory properties are the first contact that consumers have with cosmetic products, and according to Külkamp-Guerreiro et al. ${ }^{(8)}$, they relate such properties to product efficacy. In this sense, silicone-based formulations claim to have occlusive properties without oily feeling, and taking into account silicone sensory properties, consumers consider that silicone-based formulations have skin hydration properties.

Under the experimental conditions studied, skin hydration properties seem to be improved when the pearl extract was added to the formulation (vehicle) since the highest stratum corneum water content values were obtained when the formulation with pearl extract was applied. Both formulations showed increased stratum da corneum water content and, as a result, better skin hydration. Both formulations also presented protective effect on skin barrier function (by decreasing the TEWL), likely due to its occlusive effect. However, the formulation with pearl extract showed more pronounced effects for all the sensory parameters evaluated since the formulation with pearl extract showed the highest scores for all evaluated parameters. According to results of this study, it was possible to conclude that the silicone-based formulation supplemented with pearl extract could combine unique sensory properties and effectiveness to better meet consumer's demand.

\section{Acknowledgment}

The authors thank CNPq (Conselho Nacional de Desenvolvimento Científico e Tecnológico) for granting financial support for this study.

\section{Conflict of Interest}

The authors declare that there is no financial or personal relationship that could be understood as representing a potential conflict of interest. lores de viscosidade aparente mais baixos (Figura 1), provavelmente devido à característica hidrofílica deste extracto.

Sensação agradável sobre a pele durante e após a aplicação de formulações à base de silicone são amplamente descritos na literatura. Após a aplicação, os silicones podem contribuir para a suavidade da pele, proporcionar brilho ou uma aparência fosca, adicionam uma percepção hidratante, concedendo lubrificação sem pegajosidade, ou dar um, até mesmo sensação de pó seco e macio ${ }^{(3)}$.

As propriedades sensoriais são o primeiro contato que os consumidores têm com produtos cosméticos, e de acordo com Külkamp-Guerreiro et al. ${ }^{(8)}$, tais propriedades estão relacionadas à eficácia do produto. Neste sentido, as formulações à base de silicone são reivindicadas como tendo propriedades oclusivas sem sensação oleosa, e tendo em conta as propriedades sensoriais de silicone, os consumidores consideram as formulações à base de silicone como tendo propriedades de hidratação da pele.

Sob as condições experimentais deste estudo, estas características parecem ter sido melhoradas quando o extracto de pérolas foi adicionado à formulação (veículo) uma vez que os maiores valores de conteúdo aquoso do estrato córneo foram obtidos quando a formulação contendo extracto de pérola foi aplicada. Todas as formulações mostraram um aumento de conteúdo de água do estrato córneo e, como resultado, uma melhor hidratação da pele. Ambas as formulações também apresentaram efeito protetor sobre a função de barreira da pele (por diminuir o PTEA), provavelmente devido ao seu efeito oclusivo. No entanto, a formulação com extrato de pérola mostrou efeitos mais pronunciados para todos os parâmetros sensoriais avaliados, uma vez que, a formulação contendo extracto de pérola apresentou as mais altas notas para todos os parâmetros avaliados. De acordo com os resultados deste estudo, foi possível concluir que a formulação à base de silicone adicionada de extracto de pérola pode combinar propriedades sensoriais únicas e eficácia para melhor atender a demanda do consumidor.

\section{Agradecimentos}

Os autores agradecem ao CNPq (Conselho Nacional de Desenvolvimento Científico e Tecnológico) pelo financiamento deste estudo.

\section{Conflitos de interesse}

Os autores declaram que não há nenhuma relação financeira ou pessoal que possa ser entendida como representativa de um potencial conflito de interesses. 


\section{References/ Referências}

[1].Pearl extract. Cosmetic Ingredients Art No. NA21836, Technical sheet. Crodarom, France.

[2]. Glombitza B, Müller-Goymann CC. Investigation of interactions between silicones and stratum corneum lipids. Int J Cosmet Sci 2001; 23: 25-34.

[3]. Van Reeth I, Courel B, Van Doorn S. Beyond skin feel: innovative methods for developing complex sensory profiles with silicones. J Cosmet Dermatol 2006; 5(1): 61-67.

[4]. Wagemaker TAL, Silva SAM, Leonardi GR, Maia Campos PMBG. Green Coffea arabica L. seed oil influences the stability and protective effects of topical formulations. Ind Crop Prod 2014; in press
[5]. Nóbrega AT, Wagemaker TAL, Maia Campos PMBG. Antioxidant activity of Matricaria chamomilla L. extract and clinical efficacy of cosmetic formulations containing this extract and its isolated compounds. Biom Biophar Res 2013; 10(2): 249-261.

[6]. Capitani RD, Mercurio DG, Camargo Júnior FB, Maia Campos PMBG. Stability and clinical efficacy of moisturizing cosmetic formulations containing vitamin $\mathrm{C}$ and $\mathrm{E}$. Biomed Biopharm Res 2012; 9 (2): 215-224.

[7]. Savary G, Grisel M, Picard C. Impact of emollients on the spreading properties of cosmetic products: a combined of sensory and instrumental characterization. Colloids Surfaces B: Biointerfaces 2013; 102: 371-378.
[8]. Külkamp-Guerreiro IC, Berlitz SJ, Contri RV, Alves LR, Henrique EG, Barreiros VRM, Guterres SS. Influence of nanoencapsulation on the sensory properties of cosmetic formulations containing lipoic acid. Int J Cosmet Sci 2013; 35: 105-111. 